\title{
Persyn, a Member of the Synuclein Family, Has a Distinct Pattern of Expression in the Developing Nervous System
}

\author{
Vladimir L. Buchman, ${ }^{1}$ Hamish J. A. Hunter, ${ }^{1}$ Luzia G. P. Pinõn, ${ }^{1}$ Jane Thompson, ${ }^{1}$ Eugenia M. Privalova, ${ }^{1,2}$ \\ Natalia N. Ninkina, ${ }^{1,2}$ and Alun M. Davies ${ }^{1,3}$ \\ ${ }^{1}$ School of Biomedical Sciences, University of St. Andrews, Bute Medical Buildings, St. Andrews, Fife KY16 9AJ, \\ Scotland, United Kingdom, 2Institute of Gene Biology, Russian Academy of Sciences, Moscow B-334, Russia, and \\ ${ }^{3}$ Neuropa Limited, Robertson Building, Dumbarton Road, Glasgow G11 6NU, Scotland, United Kingdom
}

The synucleins are a unique family of small intracellular proteins that have recently attracted considerable attention because of their involvement in human neurodegenerative diseases. We have cloned a new member of the synuclein family called persyn. In contrast to other synucleins, which are presynaptic proteins of CNS neurons, persyn is a cytosolic protein that is expressed predominantly in the cell bodies and axons of primary sensory neurons, sympathetic neurons, and motoneurons. Northern blotting, in situ hybridization, Western blotting, and immunohistochemistry revealed that persyn mRNA and protein are expressed in these neurons from the earliest stages of axonal outgrowth and are maintained at a high level throughout life. Persyn also becomes detectable in evolutionary recent regions of the brain by adulthood.

Key words: synucleins; neurodegenerative diseases; Alzheimer's disease; Parkinson's disease; development of the nervous system; BCSG1; motoneurons; sensory neurons
The accumulation of intracellular or extracellular deposits in the form of plaques, tangles, or inclusion bodies is a hallmark of many neurodegenerative diseases (Selkoe, 1994; Kelly, 1996). These deposits are composed of one or more proteins and peptides, and it has been suggested that certain minor polypeptide components initiate aggregation of the main component (Wisniewski and Frangione, 1992; Ma et al., 1994). One of such minor components found in the plaques of Alzheimer's disease is NAC, an internal peptide of NACP or $\alpha$-synuclein, a member of a family of small proteins with an unusual amino acid sequence and undefined functions (Maroteaux et al., 1988; Maroteaux and Scheller, 1991; Uéda et al., 1993; Jakes et al., 1994). The ability of $\alpha$-synuclein to self-aggregate and to bind and induce the aggregation of amyloid A $\beta$ peptide (Iwai et al., 1995b; Yoshimoto et al., 1995; Jensen et al., 1997; Paik et al., 1997, 1998) is consistent with a potential role in promoting amyloid deposition in Alzheimer's disease. The topography of synaptic function impairment in Alzheimer's disease also correlates with the pattern of $\alpha$-synuclein expression and its localization in synaptic terminals (Uéda et al., 1993; Jakes et al., 1994; George et al., 1995; Iwai et al., 1995a). Furthermore, synuclein (synelfin) has been implicated in at least one form of learning and memory in zebrafinch (George et al., 1995; Jin and Clayton, 1997). Both $\alpha$ - and $\beta$-synucleins are expressed predominantly in evolutionary recent structures of the CNS (Maroteaux and Scheller, 1991; Uéda et al., 1993, 1994; Jakes et al., 1994).

Two mutations in the $\alpha$-synuclein gene have recently been reported to be directly associated with an early-onset, autosomaldominant form of Parkinson's disease (Polymeropoulos et al., 1997; Kruger et al., 1998). Although it has been shown that

\footnotetext{
Received June 19, 1998; revised Aug. 18, 1998; accepted Aug. 28, 1998.

This work was supported by a grant from the Wellcome Trust.

Correspondence should be addressed to Dr. V. L. Buchman, School of Biological and Medical Sciences, University of St. Andrews, Bute Medical Buildings, St. Andrews, Fife, KY16 9AJ, United Kingdom.

Copyright (C) 1998 Society for Neuroscience $\quad 0270-6474 / 98 / 189335-07 \$ 05.00 / 0$
}

synucleins in solution are random coiled or natively unfolded proteins, interactions with other macromolecules in living cells could stabilize synucleins in particular conformations (Weinreb et al., 1996; Kim, 1997; Paik et al., 1997, 1998; Davidson et al., 1998). Both mutations associated with Parkinson's disease were predicted to change the secondary structure of the $\alpha$-synuclein molecule in the way that increases the ability of this protein to self-aggregate or form aggregates with other proteins (Goedert, 1997; Heintz and Zoghbi, 1997; Nussbaum and Polymeropoulos, 1997; Polymeropoulos et al., 1997; Kruger et al., 1998). Consistently, $\alpha$-synuclein, but not $\beta$-synuclein, is found in the Lewy bodies of cases of sporadic Parkinson's disease and dementia with Lewy bodies (Spillantini et al., 1997). Accumulations of $\alpha$-synuclein are also present in abnormal neurites that, like Lewy bodies, contain ubiquitin, synaptophysin, and neurofilaments (Takeda et al., 1998). In contrast, $\tau$-positive lesions (neurofibrillary tangles, Pick's bodies, neuropil threads, and ballooned neurons) are synuclein-negative (Takeda et al., 1998). These data suggest that $\alpha$-synuclein is involved in specific aspects of the pathogenesis of neurodegeneration.

Here we report the characterization a member of the synuclein family that we have called persyn. Detailed studies of the expression of persyn mRNA and protein during normal embryonic and postnatal development show that it has a very different pattern of expression to that of other synucleins. This finding together with our evidence implicating persyn in regulating the integrity of the neurofilament network (Buchman et al., 1998) suggests that persyn could be involved in modulating axonal architecture during development and in the adult.

\section{MATERIALS AND METHODS}

Subtractive cloning. A subtractive cloning procedure (Baka and Buchman, 1996) was used to isolate cDNAs corresponding to mRNAs that are expressed at higher levels in embryonic day (E13) mouse trigeminal ganglia (TG) than in E13 mouse forebrain. Single-stranded cDNA was synthesized from E13 TG poly(A) ${ }^{+}$RNA (leader) by reverse transcrip- 
$\mathbf{a}$

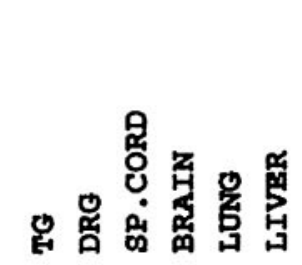

\section{PERSYN}

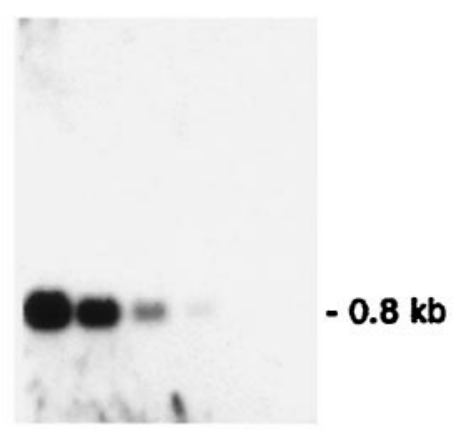

$\mathbf{L 2 7}$

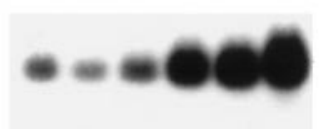

b

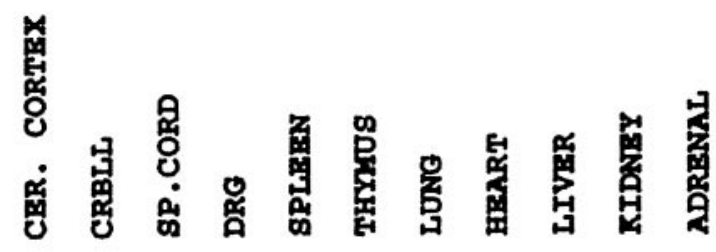

PERSYN

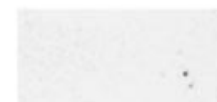

L27
$-0.8 \mathrm{~kb}$

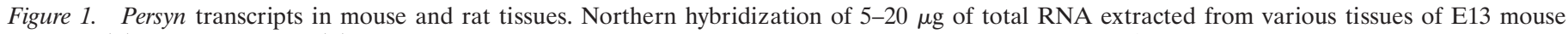

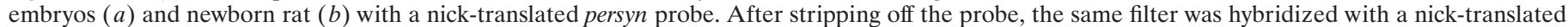

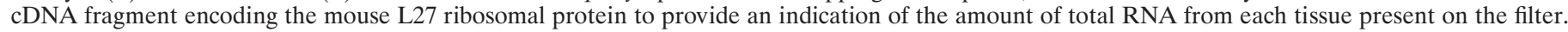
$T G$, Trigeminal ganglia; $D R G$, dorsal root ganglia.

tase, and subtractive hybridization was performed with photobiotinylated poly $(\mathrm{A})^{+}$RNA (driver). To subtract most of the housekeeping sequences, E13 mouse liver and lung poly(A) ${ }^{+}$RNAs were used as the driver in two rounds of hybridization. This was followed by two rounds of hybridization with biotinylated poly $(\mathrm{A})^{+}$RNA from E13 mouse forebrain. cDNAs that failed to form hybrids with biotinylated RNA were cloned as described (Baka and Buchman, 1996). Among the clones isolated from the resulting subtracted cDNA library were two independent overlapped clones, representing persyn mRNA.

Miscellaneous cloning procedures. RNA extraction, isolation of $\operatorname{poly}(\mathrm{A})^{+} \mathrm{RNA}$, preparation of hybridization probes, Northern, in situ, and Southern hybridizations, and library screening were performed as described (Buchman et al., 1992, 1994). Full-length cDNAs were isolated from an E13 mouse trigeminal cDNA library constructed in the $\lambda$ ZAPII vector and a cDNA library from juvenile human brainstem (Stratagene, La Jolla, CA).

Anti-persyn antibody. Rabbits were immunized with the 15-mer $\mathrm{C}$-terminal peptide of mouse persyn conjugated with keyhole limpet hemocyanin (Calbiochem, San Diego, CA) activated by MBS (Sigma, St. Louis, MO) (Harlow and Lane, 1988). Monospecific antibodies were purified from the antisera by affinity chromatography using the antigen bound to NHS-activated columns (Supelco, Bellefonte, PA). The antimouse monospecific antibody was used at dilutions of 1:500 for Western blot/ECL detection of persyn in total cell protein samples. In some experiments $10 \mathrm{ml}$ of diluted antibody was preincubated with $15 \mu \mathrm{g}$ of the recombinant mouse persyn protein at room temperature for $2 \mathrm{hr}$.

Protein extraction and Western blotting/ECL detection. Dissected trigeminal ganglia were homogenized directly in SDS-PAGE loading buffer (Laemmli, 1970) and incubated for $5 \mathrm{~min}$ in a boiling water bath. Total protein concentrations were measured by the dotMETRIC assay (Geno Technology, St. Louis, MO). Fifteen micrograms of total protein were used for SDS-PAGE (Laemmli, 1970). Electroblotting on HybondPVDF membranes was performed in Tris-glycine-methanol buffer as recommended by the membrane supplier (Amersham). Rainbow markers from Amersham were used as protein size standards. After washing with PBS, the membrane was blocked for $1 \mathrm{hr}$ at room temperature in $4 \%$ skimmed milk-0.05\% Tween 20-PBS. The same buffer was used for incubations with primary and secondary antibodies and washes. The final two washes were in $0.1 \%$ Tween $20-$ PBS. ECL detection was performed as recommended by the Amersham protocol.
Subcellular fractionation. Fractionation of homogenates of the spinal cords, trigeminal ganglia, midbrains, and hindbrains of adult mice was performed as described previously (Cotman and Taylor, 1972; Jones and Matus, 1974). Aliquots of the homogenate (hmg), 1000 gm supernatant (cyt), 14,000 gm supernatant (pmt), 14,000 gm pellet (msk), 120,000 gm supernatant (pmc), 120,000 gm pellet (mcs), mitochondrial (mt), and synaptosomal (syn) fractions of the sucrose gradient were mixed with equal volumes of $2 \times$ loading buffer (Laemmli, 1970) and incubated for 5 $\mathrm{min}$ in a boiling water bath. Twenty micrograms of total protein from each fraction were used for SDS-PAGE followed by Western blotting and detection as described above.

Immunohistochemistry. Fifteeen micrometer cryosections were fixed in acetone at $-20^{\circ} \mathrm{C}$ for $10 \mathrm{~min}$ and were dried and blocked with $5 \%$ goat serum in TBT $(20 \mathrm{~mm}$ Tris $\mathrm{HCl}, \mathrm{pH} 7.5 ; 150 \mathrm{~mm} \mathrm{NaCl}$; and $0.1 \%$ Triton $\mathrm{X}-100)$ followed by incubation with the anti-persyn antibody $(1: 50)$ at $4{ }^{\circ} \mathrm{C}$ for $16 \mathrm{hr}$ in $1 \%$ goat serum-TBT. Sections were washed with $1 \%$ goat serum-TBT and processed as recommended by suppliers of secondary HRP-conjugated antibody (Sigma). The same procedure was used for cultured neurons fixed on the Petri dish with cold acetone-methanol mixture (1:1). FITC-conjugated secondary anti-rabbit antibody (Jackson ImmunoResearch, West Grove, PA) was used for detection.

\section{RESULTS}

\section{Cloning of persyn cDNA}

persyn cDNA clones were isolated using the subtractive cloning procedure described in Materials and Methods. Using the insert of the longest clone as a probe for Northern hybridization, a single $0.8 \mathrm{~kb}$ transcript was detected only in neural tissues of the E13 mouse embryo. The level of this transcript was much higher in sensory ganglia (trigeminal and dorsal root ganglia) than in CNS, reflecting the way in which the clone was isolated (Fig. 1a). Similar results were obtained when the mouse persyn probe was used for hybridization with RNAs from newborn rat tissues (Fig. 1b).

To isolate a full-length persyn cDNA, an E13 mouse trigeminal ganglion cDNA library was constructed and screened with the 


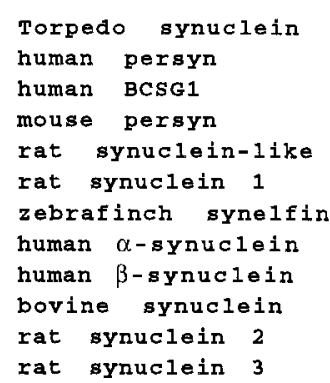

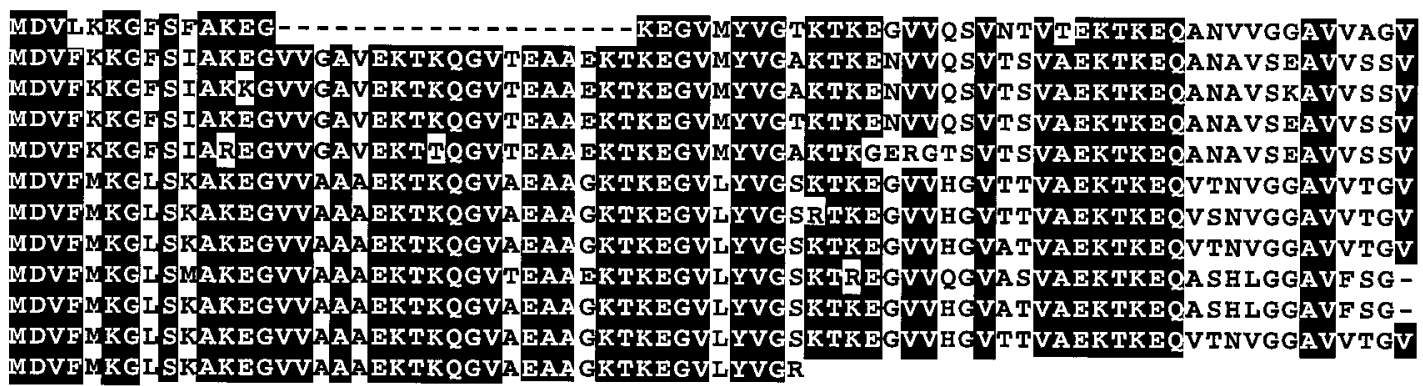

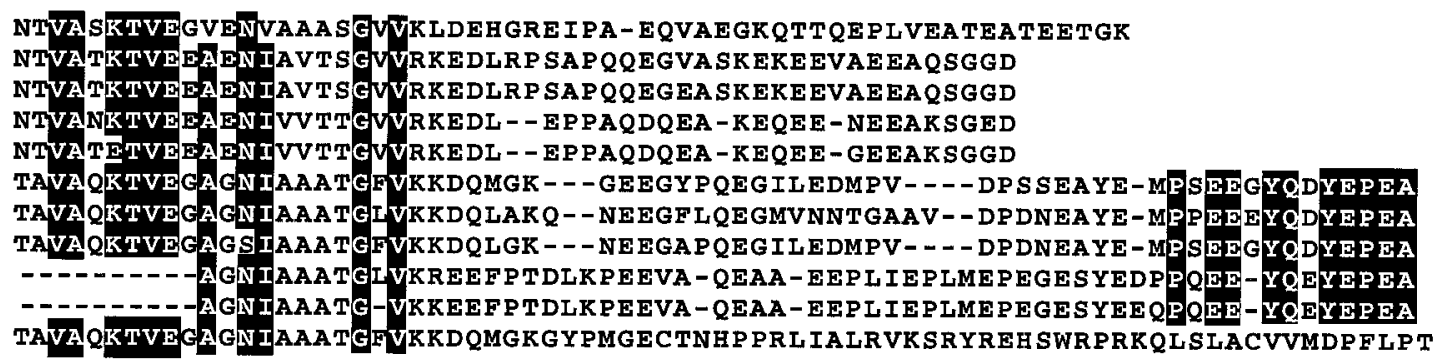

Figure 2. Homologies between mouse persyn and other members of the synuclein family. Alignment of persyn and other members of the synuclein family. Amino acids identical in all or in all but one members of the family are shown in white on black background. Gaps (-) were introduced for better alignment. Sequence accession numbers: Torpedo californica synuclein, P37379; rat synucleins 1, 2, 3, products of alternative splicing of the same gene S73007, S73008, S73009; human $\alpha$-synuclein (synuclein 1/NACP), L36674; human $\beta$-synuclein (synuclein 2), S69965; bovine synuclein, P33567; zebrafinch synelfin, L33860; rat synuclein-like, X86789; human BCSG1, AF010126; mouse persyn, AF017255; human persyn, AF017256.

mouse persyn cDNA probe. Four overlapping cDNA clones were isolated from this screen, and sequence analysis revealed that the longest of these included 5' untranslated, coding and 3' untranslated (with a characteristic polyadenylation signal) regions (GenBank accession number AF017255). Two human persyn cDNA clones were isolated by screening a juvenile brainstem cDNA library with the mouse probe at low stringency. One of these clones included the complete coding region for human persyn protein (GenBank accession number AF017256).

\section{Persyn is a member of the synuclein family}

Figure 2 shows the high degree of homology between persyn and other synucleins. All of the EKTKEGV repeats, which are characteristic of the family (Maroteaux et al., 1988; Maroteaux and Scheller, 1991; Uéda et al., 1993; Jakes et al., 1994), are conserved in persyn. The C-terminal region of persyn is highly negatively charged (12 of last 26 amino acids are glutamic or aspartic acid residues), and this region has no obvious homology with other synucleins. The C-terminal amino acid sequences in most synucleins are variable and negatively charged (with the exception of rat synuclein 2, which is charged positively). The sequence of persyn is closely related to the sequence of the founder of the family, Torpedo synuclein (Maroteaux et al., 1988). Two previously published EST sequences that are most closely related to persyn [rat synuclein-like (Akopian and Wood, 1995) and human BCSG1 (Ji et al., 1997)] have multiple substitutions of amino acid that are highly conserved in the synuclein family (Fig. 2). These substitutions are probably resulted from Taq polymerase and sequence errors.

\section{persyn mRNA is expressed in embryonic sensory and motoneurons}

A digoxygenin-labeled cRNA probe was used for whole-mount in situ hybridization of E11 mouse embryos. Consistent with the results of Northern hybridization, signals were detected in all dorsal root ganglia (DRG) and cranial sensory ganglia and in two strips within the spinal cord (Fig. 3). For precise localization of persyn-positive cells, in situ hybridization on cryosections was performed. At E10, before the formation of DRG, signals were only detected in the ventral horns of the spinal cord in transverse sections (Fig. 4a). In E11 and E12 embryos, when DRG have become evident, signals were additionally detected in DRG (Fig. $4 a$ ). Signals were also observed in all cranial sensory ganglia and in the regions of the hindbrain and midbrain where branchiomotor and somatomotor neurons are located. This is illustrated in the coronal section of an E11 head where hybridization signals in the motoneurons of oculomotor nucleus can be seen (Figs. 4b,c). On transverse sections of postnatal day 9 (P9) mice, persyn mRNA was detected in ventral horn motoneurons, most if not all DRG neurons and in the neurons of paravertebral sympathetic chain (Fig. $5 a, b)$.

\section{Persyn in adult brain}

Although no persyn protein and mRNA were detected in embryonic and neonatal forebrain structures (Figs. 1, 3, 4) accumulation of persyn protein in the cerebral cortex with age was observed using Western blotting (Buchman et al., 1998). To reveal which kinds of cells express persyn mRNA in adult brain we localized persyn mRNA by in situ hybridization in parasagital cryosections of rat brain. The strongest hybridization signals were detected in the motoneurons of the brainstem (Fig. 6a). However, substantial levels of expression were found in neurons in many other brain regions including: Purkinje and granule cell layers of the cerebellar cortex and the deep cerebellar nuclei, thalamus, hypothalamus, olfactory bulbs, CA1, CA2, CA 3 , and CA4 regions of the hippocampus, and all neuron-containing layers of the cerebral cortex in all regions examined (Fig. 6). 

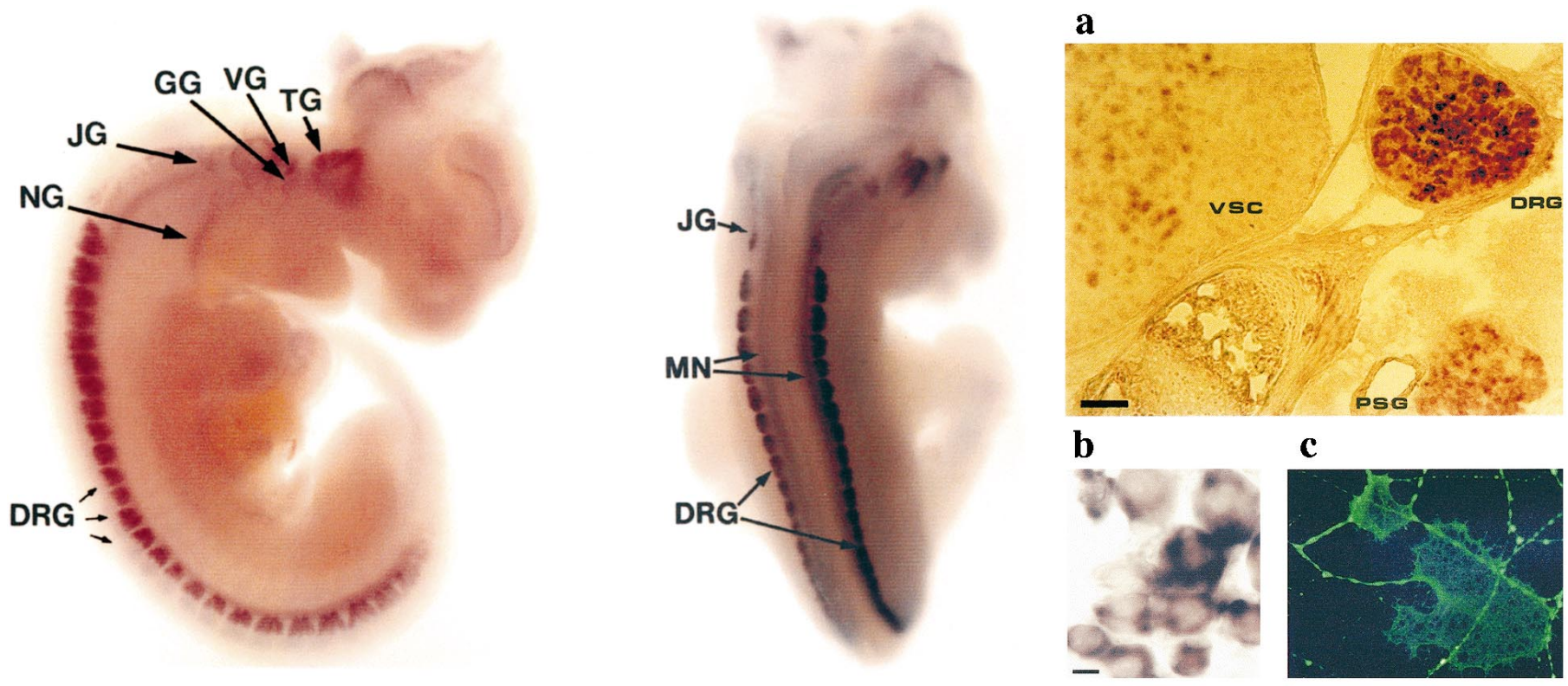

$\mathbf{a}$
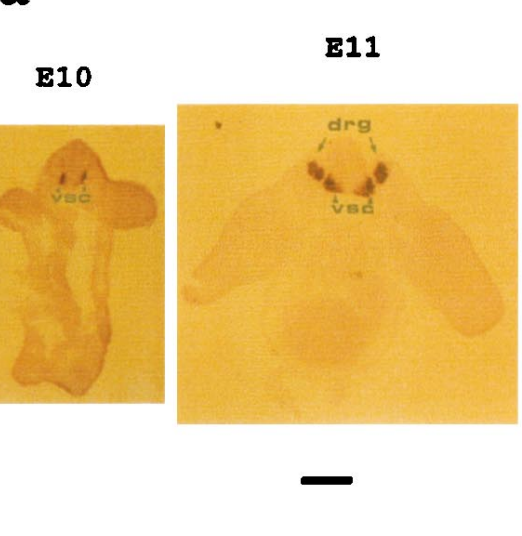

\section{b}

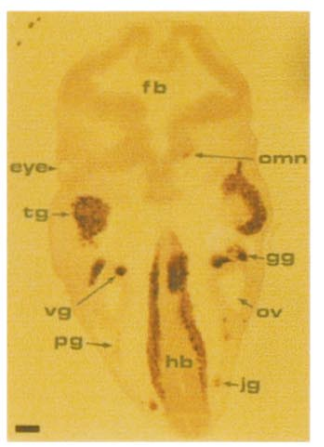

c

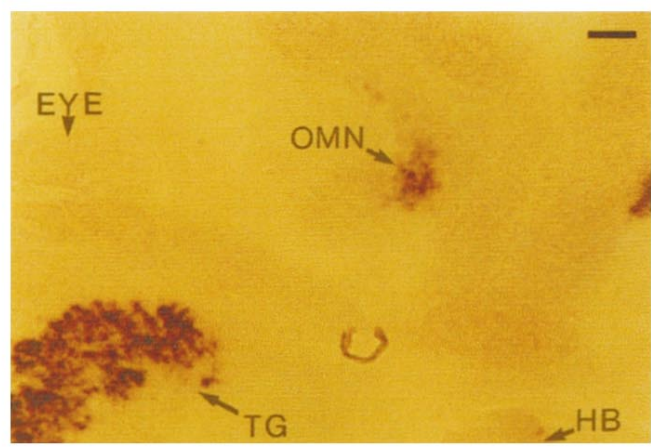

a

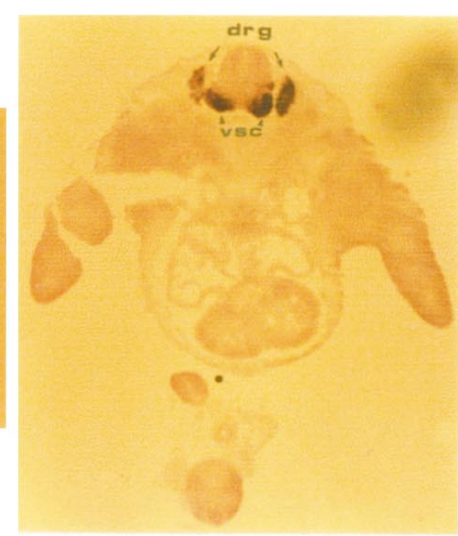

EI2

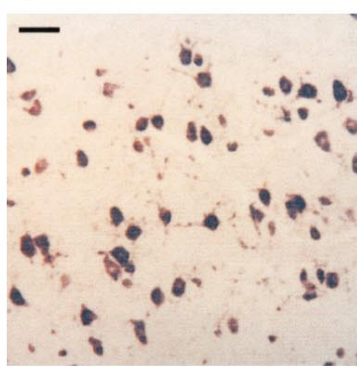

c

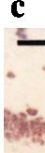

- b

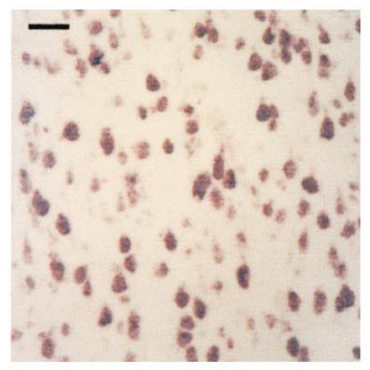

d

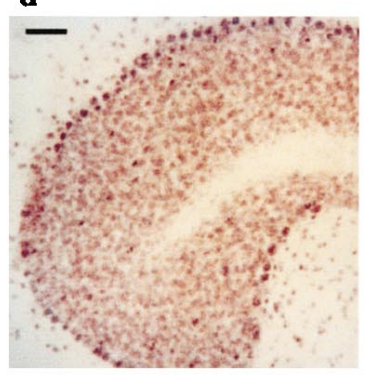

f

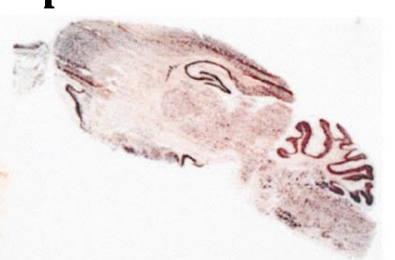

Figure 3. Top Left. Whole-mount in situ hybridization of mouse embryos. E11 mouse embryos were hybridized with a DIG-labeled antisense cRNA persyn probe. $T G$, Trigeminal ganglion; $V G$, vestibular ganglion; $G G$, geniculate ganglion; $J G$, jugular ganglion; $N G$, nodose ganglion; $D R G$, dorsal root ganglia; $M N$, motoneurons in ventral horns of the spinal cord.

Figure 4. Bottom left. Detection of persyn expression in mouse embryonic tissues by in situ hybridization. $a$, Transverse sections at the level of the forelimb buds of E10,E11, and E12 embryos were hybridized with a DIG-labeled antisense cRNA persyn probe. vsc, Motoneurons in ventral horns of the spinal cord; $\mathrm{drg}$, dorsal root ganglia. Scale bar, $1 \mathrm{~mm}$. $b$, Coronal section of E11 mouse embryo head. tg, Trigeminal ganglion; $v g$, vestibular ganglion; $g g$, geniculate ganglion; $j g$, jugular ganglion; $p g$, petrosal ganglion; $o v$, otic vesicle; $h b$, hindbrain; $f b$, forebrain; omn, oculomotor nucleus. Scale bar, 0.2 $\mathrm{mm} . c$, A higher magnification of a coronal section of an E11 mouse embryo head showing strong labeling in the oculomotor nucleus and trigeminal ganglion. Scale bar, $80 \mu \mathrm{m}$. 


\section{Regulation of persyn expression during development of mouse trigeminal ganglion}

Because the normal development of the embryonic mouse trigeminal ganglion is known in detail (Davies and Lumsden, 1984, 1986), the expression of persyn was studied in this ganglion at closely staged intervals throughout development to ascertain when persyn is first expressed and how its expression changes during development. Quantitative Northern hybridization revealed that persyn mRNA is expressed in the trigeminal ganglion from the earliest stages of its formation. There was a marked increase in expression between E10 and E12, the stage during which the earliest axons are growing to their targets. This high level of expression was maintained into adulthood (Fig. 7A). Western blotting revealed that the developmental time course of persyn protein expression in the trigeminal ganglion (Fig. $7 B$ ) was consistent with the time course of persyn mRNA expression observed in Northern blotting studies.

\section{Persyn is cytosolic protein localized in neuronal cell bodies and processes}

Specific polyclonal antibodies (SK23) were raised in rabbits against a synthetic C-terminal 15 -mer peptide (PS) of mouse persyn. These antibodies detected a single band of $\sim 16 \mathrm{kDa}$ on Western blots that disappeared if the antibodies were preincubated with excess of either the C-terminal peptide or a recombinant persyn protein (Fig. $8 a, b$; data not shown). The mobility of the protein was $3 \mathrm{kDa}$ more than expected from the persyn sequence, but similar decreases in mobility have been reported for other synucleins (Jakes et al., 1994; Weinreb et al., 1996). This antibody does not cross-react with either recombinant $\alpha$ - or $\beta$-synucleins and does not detect native $\alpha$-and $\beta$-synucleins in the newborn mouse cerebral cortex (Fig. $8 c$ ), the tissue where these proteins could be easy detected with specific antibody (Shibayama-Imazu et al., 1993; Hsu et al., 1998).

Western blotting was used to study the distribution of persyn in subcellular fractions of the mouse spinal cord, trigeminal ganglion, midbrain, and hindbrain. Persyn protein was detected only in the cytosolic fractions but not in the particulate and cytoskeletal fractions (Fig. 9). Immunohistochemistry using the SK23 antibodies has shown that persyn is localized in the cell bodies and axons of sensory neurons (Buchman et al., 1998). Likewise, immunocytochemical detection of persyn in cultured DRG neurons showed that persyn is present in the cell bodies, processes, and growth cones of these neurons (Fig. $5 c$ ) and that it is expressed in both large NT3-dependent and small NGF-dependent neurons (Fig. $5 b$; data not shown).

\section{DISCUSSION}

We have cloned and characterized a member of the synuclein family that has a distinctive pattern of expression in the developing and mature nervous system. Persyn shares the main structural features of the family, namely, conservation of all EKTKEGV
A

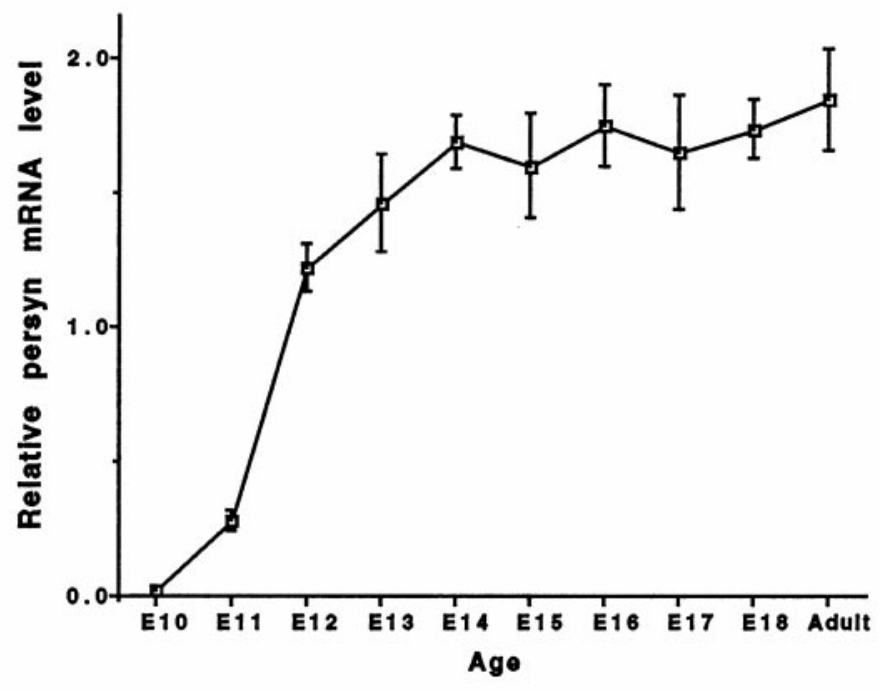

B

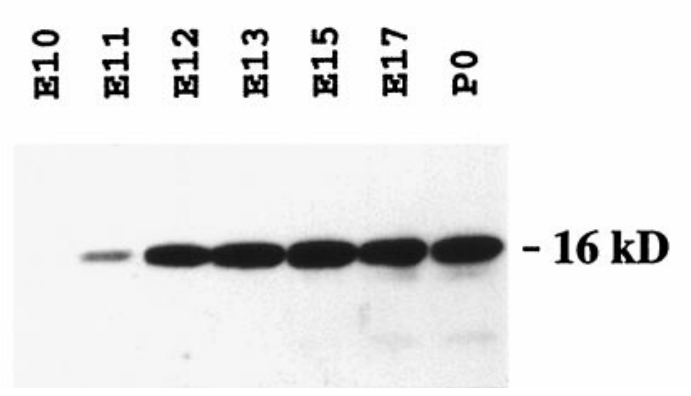

Figure 7. Developmental time course of persyn expression in the trigeminal ganglia. $a$, Graph showing the changes in the level of persyn mRNA in the trigeminal ganglia during development. The mean \pm SEM of the persyn mRNA levels relative to GAPDH mRNA levels are shown $(n=3)$. $b$, Western blot showing the developmental changes in the level of persyn protein the trigeminal ganglia. Equal amounts $(15 \mu \mathrm{g})$ of total protein from embryonic $(E)$ or newborn $(P O)$ mouse trigeminal ganglia were run in each lane.

repeats and the $\mathrm{C}$-terminal part of the molecule is negatively charged. In contrast to $\alpha$ - and $\beta$-synucleins, which are predominantly expressed in the cerebral cortex and other forebrain structures (Uéda et al., 1993, 1994; Jakes et al., 1994; George et al., 1995; Iwai et al., 1995a), persyn is abundant in primary sensory neurons and motoneurons. These are the only neurons that express persyn in embryos, although persyn is expressed in sympathetic ganglia in neonates and many different kinds of neurons throughout the brain in the adult.

\section{$\leftarrow$}

Figure 5. Top right. Detection of persyn expression in mouse postnatal neurons. $a$, In situ hybridization of transverse section through the thorax of a P9 mouse neonate with a DIG-labeled antisense cRNA persyn probe. VSC, Motoneurons of the ventral horns of the spinal cord; DRG, dorsal root ganglion; PSG, paravertebral sympathetic ganglia. Scale bar, $0.2 \mathrm{~mm}$. $b$, Higher magnification of part of the DRG illustrated in the panel ( $a$ ) showing the cytoplasmic labeling of neurons. $c$, Immunocytochemical localization of persyn protein in processes and growth cones of cultured mouse DRG neurons. Scale bar, $20 \mu \mathrm{m}$.

Figure 6. Bottom right. Detection of persyn expression in adult brain by in situ hybridization. In situ hybridization of parasagittal sections of adult rat brain with a DIG-labeled antisense cRNA persyn probe. Labeled neurons within the trigeminal motor nucleus $(a)$, frontal cortex $(b)$, CA1, and CA3 regions of hippocampus and cerebellar cortex are shown. Scale bars: $a, b, 0.1 \mathrm{~mm} ; c, d, 0.2 \mathrm{~mm}$. The whole brain images demonstrating absence of hybridization with persyn cDNA sense probe $(e)$ and specific hybridization with persyn cDNA antisense probe $(f)$ are shown. 
Figure 8. Specificity of anti-mouse persyn antibody. Western blot/ECL detection of persyn protein with affinity-purified SK-23 antibody. $a, b$, Equal amounts $(15 \mu \mathrm{g})$ of total protein from $\mathrm{P} 0$ mouse heart and hindbrain and E13 and E17 trigeminal ganglia were run in each lane. Western blots were probed with SK-23 antibody $(a)$ or SK-23 antibody preincubated with recombinant mouse persyn protein $(b)$ as described in Materials and Methods. $c$, Fifteen micrograms of total protein from newborn (P0) mouse trigeminal ganglia (the tissue with a high level of persyn expression) and cerebral cortex (the tissue where persyn expression could not be detected but with substantial levels of $\alpha$ - and $\beta$-synucleins expression) and $0.5 \mu \mathrm{g}$ of recombinant $\alpha$ - and $\beta$-synucleins were analyzed. $\mathbf{a}$

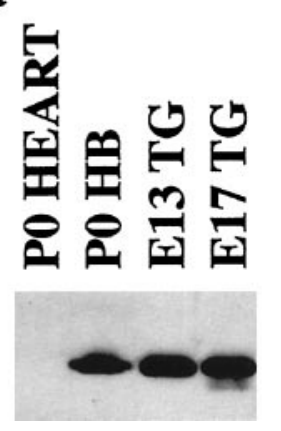

b

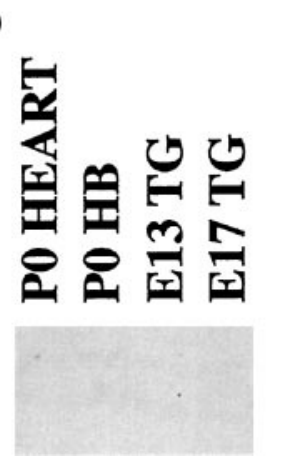

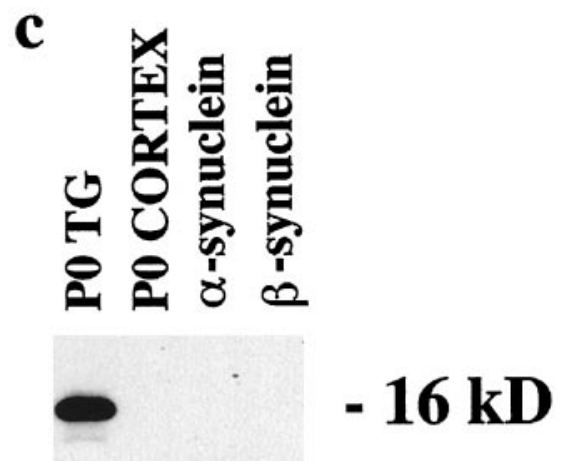

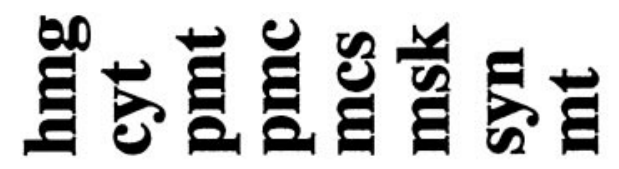

$-16 \mathrm{kD}$

Figure 9. Persyn in subcellular fractions from mouse spinal cord. Western blot showing the distribution of persyn protein in subcellular fractions of the adult mouse spinal cord. hmg, Homogenate; cyt, $1000 \mathrm{gm}$ supernatant; pmt, 14,000 gm supernatant; pmc, 120,000 gm supernatant; mcs, $120,000 \mathrm{gm}$ pellet; $m s k, 14,000 \mathrm{gm}$ pellet; $m t$, mitochondrial fraction; syn, synaptosomal fraction. Equal amounts $(15 \mu \mathrm{g})$ of total protein from each fraction were run in each lane. Very similar results were obtained with subcellular fractions of trigeminal ganglia, midbrain, and hindbrain.

Immunocytochemical studies suggest that persyn is distributed diff usely throughout the cell body and axons of sensory neurons and motoneurons. This agrees with the results of subcellular fractionation of mouse neuronal tissues that show that persyn is a predominantly cytosolic protein that is not or very loosely associated with cytoskeletal or vesicular fractions. This is similar to the intracellular distribution of human and rat synucleins and zebrafinch synelfin (George et al., 1995; Irizarry et al., 1996). However, both $\alpha$ - and $\beta$-synuclein are apparently predominantly presynaptic proteins in the cerebral cortex (Iwai et al., 1995a; Masliah et al., 1996; Irizarry et al., 1996).

Although the physiological role of synucleins is unknown, it has been suggested that specific mutations could change the structural and functional properties of these proteins, triggering mechanisms that lead to neurodegeneration (Goedert, 1997; Heintz and Zoghbi, 1997; Nussbaum and Polymeropoulos, 1997; Polymeropoulos et al., 1997). Interestingly, human persyn has a threonin in position 53, which makes it structurally similar to mutated (Ala53Thr) $\alpha$-synuclein found in some families with hereditary early-onset form of Parkinson's disease (Polymeropoulos et al., 1997). However, what kind of structural and functional consequences this difference could have is not clear. Although it was speculated that Ala53Thr substitution disrupts an $\alpha$-helix and extends a $\beta$-sheet in the predicted structure in this part of the molecule (Polymeropoulos et al., 1997), all experimental attempts to resolve the secondary structure of the wild-type $\alpha$-synuclein have led to conclusion that synucleins are "natively unfolded" or random coiled in solution (Weinreb et al., 1996; Kim, 1997). However, it was shown that binding to synthetic membranes stabilizes $\alpha$-synuclein in an $\alpha$-helical conformation (Davidson et al., 1998). Perhaps synucleins exist in different conformations in cells depending on their association with membranes, and it is possible that soluble and membrane-bound forms could have different functions.

We have recently shown that persyn plays role in regulating the integrity of the neurofilament network in cultured sensory neurons (Buchman et al., 1998). In this respect, it is interesting that the onset of persyn expression in trigeminal sensory neurons coincides with the stage when axons are starting to grow to their targets and remains high throughout the life, raising the possibility that persyn plays a role in regulating axonal growth and influencing axonal morphology.

The effect of persyn on neurofilaments could be important in neurodegenerative conditions especially given the accumulation of persyn in neurons of the cerebral cortex with age and its localization within axons. Loss of nerve cell processes is believed to contribute significantly to cerebral atrophy in neurodegenerative diseases. Understanding the pathophysiology of this process is important for developing therapeutic strategies to prevent loss of neuronal connectivity. In further work it will be important to investigate the possible contribution of persyn to the loss of neurons and their processes in neurodegenerative diseases.

\section{REFERENCES}

Akopian AN, Wood JN (1995) Peripheral nervous system-specific genes identified by subtractive cDNA cloning. J Biol Chem 270:21264-21270.

Baka ID, Buchman VL (1996) Subtractive cDNA cloning from limited amounts of biological material. Anal Biochem 237:155-157.

Buchman VL, Ninkina NN, Bogdanov YD, Bortvin AL, Akopian HN, Kiselev SL, Krylova OY, Anokhin KV, Georgiev GP (1992) Differential splicing creates a diversity of transcripts from a neurospecific developmentally regulated gene encoding a protein with new zincfinger motifs. Nucleic Acids Res 20:5579-5585.

Buchman VL, Sporn M, Davies AM (1994) Role of transforming growth factor-beta isoforms in regulating the expression of nerve growth factor and neurotrophin-3 mRNA levels in embryonic cutaneous cells at different stages of development. Development 120:1621-1629.

Buchman VL, Adu J, Pinõn LGP, Ninkina NN, Davies AM (1998) Persyn, a member of the synuclein family, influences neurofilament network integrity. Nat Neurosci 1:101-103.

Cotman CW, Taylor D (1972) Isolation and structural studies on synaptic complexes from rat brain. J Cell Biol 55:696-711.

Davidson WS, Jonas A, Clayton DF, George JM (1998) Stabilization of $\alpha$-synuclein secondary structure upon binding to synthetic membranes. J Biol Chem 273:9443-9449. 
Davies AM, Lumsden AGS (1984) Relation of target encounter and neuronal death to nerve growth factor responsiveness in the developing mouse trigeminal ganglion. J Comp Neurol 223:124-137.

Davies AM, Lumsden AG (1986) Fasciculation in the early mouse trigeminal nerve is not ordered in relation to the emerging pattern of whisker follicles. J Comp Neurol 253:13-24.

George JM, Jin H, Woods WS, Clayton DF (1995) Characterization of a novel protein regulated during the critical period for song learning in the zebra finch. Neuron 15:361-372.

Goedert M (1997) The awakening of $\alpha$-synuclein. Nature 388:232-233.

Harlow E, Lane D (1988) Antibodies: a laboratory manual. New York: Cold Spring Harbor Laboratory.

Heintz N, Zoghbi H (1997) $\alpha$-synuclein - a link between Parkinson and Alzheimer diseases? Nat Genet 16:325-327.

Hsu LJ, Mallory M, Xia Y, Veinbergs I, Hashimoto M, Yoshimoto M, Thal LJ, Saitoh T, Masliah E (1998) Expression pattern of synucleins (non-A $\beta$ component of Alzheimer's disease amyloid precursor protein/ $\alpha$-synuclein) during murine brain development. J Neurochem 71:338-344.

Irizarry MC, Kim TW, McNamara M, Tanzi RE, George JM, Clayton DF, Hyman BT (1996) Characterization of the precursor protein of the non- $\mathrm{A} \beta$ component of senile plaques (NACP) in the human central nervous system. J Neuropathol Exp Neurol 55:889-895.

Iwai A, Masliah E, Yoshimoto M, Ge N, Flanagan L, de Silva HAR, Kittel A, Saitoh T (1995a) The precursor protein of non-A $\beta$ component of Alzheimer's disease amyloid is a presynaptic protein of the central nervous system. Neuron 14:467-475.

Iwai A, Yoshimoto M, Masliah E, Saitoh T (1995b) Non-A $\beta$ component of Alzheimer's disease amyloid (NAC) is amyloidogenic. Biochemistry 34:10139-10145.

Jakes R, Spillantini MG, Goedert M (1994) Identification of two distinct synucleins from human brain. FEBS Lett 345:27-32.

Jensen PH, Hojrup P, Hager H, Nielsen MS, Jacobsen L, Olesen OF, Gliemann J, Jakes R (1997) Binding of $\mathrm{A} \beta$ to $\alpha$ - and $\beta$-synucleins: identification of segments in $\alpha$-synuclein/NAC precursor that bind $\mathrm{A} \beta$ and NAC. Biochem J 323:539-546.

Ji H, Liu YE, Jia T, Wang M, Liu J, Xiao G, Joseph BK, Rosen C, Shi YE (1997) Identification of a breast cancer-specific gene, BCSG1, by direct differential cDNA sequencing. Cancer Res 57:759-764.

Jin H, Clayton DF (1997) Synelfin regulation during the critical period for song learning in normal and isolated juvenile zebra finches. Neurobiol Learn Mem 68:271-284.

Jones DH, Matus AI (1974) Isolation of synaptic plasma membrane from brain by combined flotation-sedimentation density gradient centrif ugation. Biochim Biophys Acta 356:276-287.

Kelly JW (1996) Alternative conformations of amyloidogenic proteins govern their behavior. Curr Opin Struct Biol 6:11-17.

Kim J (1997) Evidence that the precursor protein of non-A $\beta$ component of Alzheimer's disease amyloid (NACP) has an extended structure primarily composed of random-coil. Mol Cells 7:78-83.

Kruger R, Kuhn W, Muller T, Woitalla D, Graeber M, Kosel S, Przuntek H, Epplen JT, Schols L, Riess O (1998) Ala30Pro mutation in the gene encoding $\alpha$-synuclein in Parkinson's disease. Nat Genet 18:106-110.

Laemmli EK (1970) Cleavage of structural proteins during the assembly of the head of bacteriophage T4. Nature 227:680-685.

Ma J, Yee A, Brewer Jr HB, Das. S, Potter H (1994) Amyloid-associated proteins a1-antichymotrypsin and apolipoprotein E promote assembly of Alzheimer $\beta$-protein into filaments. Nature 372:92-94.

Maroteaux L, Scheller RH (1991) The rat brain synucleins; family of proteins transiently associated with neuronal membrane. Mol Brain Res 11:335-343.

Maroteaux L, Campanelli JT, Scheller RH (1988) Synuclein: a neuronspecific protein localized to the nucleus and presynaptic nerve terminal. J Neurosci 8:2804-2815.

Masliah E, Iwai A, Mallory M, Ueda K, Saitoh T (1996) Altered presynaptic protein NACP is associated with plaque formation and neurodegeneration in Alzheimer's disease. Am J Pathol 148:201-210.

Nussbaum RL, Polymeropoulos MH (1997) Genetics of Parkinson's disease. Hum Mol Genet 6:1687-1691.

Paik SR, Lee JH, Kim DH, Chang CS, Kim J (1997) Aluminuminduced structural alterations of the precursor of the non-A $\beta$ component of Alzheimer's disease amyloid. Arch Biochem Biophys 344:325-334.

Paik SR, Lee JH, Kim DH, Chang CS, Kim YS (1998) Selfoligomerization of NACP, the precursor protein of the non-amyloid $\beta / \mathrm{A} 4$ protein $(\mathrm{A} \beta)$ component of Alzheimer's disease amyloid, observed in the presence of a $\mathrm{C}$-terminal $\mathrm{A} \beta$ fragment (residues 25-35). FEBS Lett 421:73-76.

Polymeropoulos MH, Lavedan C, Leroy E, Ide SE, Dehejia A, Dutra A, Pike B, Root H, Rubenstein J, Boyer R, Stenroos ES, Chandrasekharappa S, Athanassiadou A, Papapetropoulos T, Johnson WG, Lazzarini AM, Duvoisin RC, Di Iorio G, Golbe LI, Nussbaum RL (1997) Mutation in the $\alpha$-synuclein gene identified in families with Parkinson's disease. Science 276:2045-2047.

Selkoe DJ (1994) Normal and abnormal biology of the $\beta$-amyloid precursor protein. Annu Rev Neurosci 17:487-517.

Shibayama-Imazu T, Okahashi I, Omata K, Nakajo S, Ochiai H, Nakai Y, Hama T, Nakamura Y, Nakaya K (1993) Cell and tissue distribution and developmental change of neuron specific $14 \mathrm{kDa}$ protein (phosphoneuroprotein 14). Brain Res 622:17-25.

Spillantini MG, Schmidt ML, Lee VM-Y, Trojanowski JQ, Jakes R, Goedert M (1997) $\alpha$-synuclein in Lewy bodies. Nature 388:839-840.

Takeda A, Mallory M, Sundsmo M, Honer W, Hansen L, Masliah E (1998) Abnormal accumulation of NACP/ $\alpha$-synuclein in neurodegenerative disorders. Am J Pathol 152:367-372.

Uéda K, Fukushima H, Masliah E, Xia Y, Iwai A, Yoshimoto M, Otero DAC, Kondo J, Ihara Y, Saitoh T (1993) Molecular cloning of cDNA encoding an unrecognized component of amyloid in Alzheimer disease. Proc Natl Acad Sci USA 90:11282-11286.

Uéda K, Saitoh T, Mori H (1994) Tissue-dependent alternative splicing of mRNA for NACP, the precursor of non-A $\beta$ component of Alzheimer's disease amyloid. Biochem Biophys Res Commun 205:1366-1372.

Weinreb PH, Zhen W, Poon AW, Conway KA, Lansbury Jr PT (1996) NACP, a protein implicated in Alzheimer's disease and learning, is natively unfolded. Biochemistry 35:13709-13715.

Wisniewski T, Frangione B (1992) Apolipoprotein E: a pathological chaperone protein in patients with cerebral and systemic amyloid. Neurosci Lett 135:235-238.

Yoshimoto M, Iwai A, Kang D, Otero DAC, Xia Y, Saitoh T (1995) $\mathrm{NACP}$, the precursor protein of the non-amyloid $\beta / \mathrm{A} 4$ protein $(\mathrm{A} \beta)$ component of Alzheimer disease amyloid, binds $\mathrm{A} \beta$ and stimulates $\mathrm{A} \beta$ aggregation. Proc Natl Acad Sci USA 92:9141-9145. 